\title{
Analyzing and Adjusting for Nonresponse to the AFRP Spouse Survey
}

\author{
Vincent G. lannacchione and Jennifer G. Milne \\ Research Triangle Institute
}

\author{
Personnel Utilization Technical Area \\ Paul A. Gade, Chief \\ Manpower and Personnel Research Laboratory \\ Zita M. Simutis, Director \\ U.S. Army Research Institute for the Behavioral and Social Sciences \\ 5001 Eisenhower Avenue, Alexandria, Virginia 22333-5600 \\ Office, Deputy Chief of Staff for Personnel \\ Department of the Army \\ November 1991
}

